\title{
Autoria e estilo: um caso concreto do autor-criador no gênero discursivo panfleto
}

\author{
Pedro Farias Francelino" \\ Elias Coelho da Silva**
}

\section{Resumo}

O objetivo deste trabalho é demonstrar que autor e interlocutor se encontram imanentemente implicados na construção estilística do enunciado e que a relação entre eles, determinada pelas condições sócio-históricas de produção, é materializada na forma de posições axiológicas refletidas e refratas no enunciado. Para evidenciar esse propósito, foi analisado um panfleto divulgado nas eleições de 2020 para prefeitura de Recife-PE. Como referencial teórico, utilizamos as concepções de autor e estilo com base no aparato teórico de Bakhtin (2011), Volóchinov (2002), dentre outros.

Palavras-chave: Autor; interlocutor; estilo.

\section{Introdução}

Recorrente no âmbito dos estudos literários, a questão do estilo e da autoria ganha diferentes nuances quando anali-

* Doutor em Linguística pela Universidade Federal de Pernambuco (UFPE). Mestre em Língua Portuguesa pela Universidade Federal da Paraíba (UFPB). Pós-doutorado em Linguística pela Universidade Católica de Pernambuco (UNICAP). É Professor Associado do Departamento de Língua Portuguesa e Linguística da UFPB e docente do Programa de Pós-graduação em Linguística da mesma instituição. Foi vice-coordenador do GT Anpoll Estudos Bakhtinianos (biênio 2014-2016) e Coordenador desse grupo no biênio 2016-2018. É líder do Grupo de Pesquisa em Linguagem, Enunciação e Interação (CNPq/UFPB). Atua nas áreas de Língua Portuguesa e Linguística, desenvolvendo pesquisas em teorias do discurso, especificamente a perspectiva dialógica dos estudos da linguagem. pedrofrancelino@yahoo.com.br

** Graduação em Letras pela Universidade de Pernambuco. Especialização em Linguística Aplicada a Práticas Discursivas pela FAFIRE - Faculdade Frassinetti do Recife. Mestrado em Linguística pela Universidade Federal da Paraíba - UFPB e doutorando em Linguística pelo Programa de Pós-Graduação em Linguística da UFPB. É professor EBTT do Instituto Federal de Educação, Ciência e Tecnologia do Sertão Pernambucano (IF Sertão-PE / Campus Ouricuri) e integrante do grupo de pesquisa A Análise do Discurso e suas interfaces (GEDISPE IF Sertão-PE / Campus Ouricuri) com interesse na construção de identidades estereotipadas e nas diferentes representações do sertão. E-mail: elias. coelho@ifsertao-pe.edu.br

Data de submissão: abr. 2021 - Data de aceite: jul. 2021 http://dx.doi.org/10.5335/rdes.v17i2.12668 
sada em diferentes vertentes de análise do discurso. Para Foucault (1969), o autor é uma função social do sujeito. Barthes (1986), por sua vez, concebe-a como uma dispersão na linguagem. De uma forma ou de outra, o autor passa a figurar nos estudos do discurso menos como individualidade que como uma fragmentação de sujeitos e atos sociais na e pela linguagem.

Neste trabalho, adotamos outra perspectiva, embora alinhada às vertentes discursivas de análise do sujeito e da autoria, a da Análise Dialógica do Discurso, ancorada nas investigações desenvolvidas pelo Círculo de Bakhtin. Nosso intento é reafirmar a ideia de que $o$ autor não se confunde com o indivíduo, pois se constitui como uma entidade imanentemente discursiva, instaurada nos enunciados pelos agentes cognoscentes no mundo a partir das diferentes situações sócio-históricas de interação social.

Partindo desse viés, o objetivo consiste em demonstrar que autor e interlocutor se encontram imanentemente implicados na construção estilística do enunciado e que a relação entre eles, determinada pelas condições sócio-históricas de produção, é materializada na forma de posições axiológicas refletidas e refratadas no interior do enunciado.

Para isso, primeiramente discutimos as noções de sujeito, autoria e estilo com base em Bakhtin e Volóchinov para delimitar a abrangência de nossa perspectiva e esclarecer os pontos de partida de nossa reflexão. Em seguida, procedemos a uma análise qualitativa e interpretativa de um enunciado concreto, investigando os recursos estilísticos empregados em um panfleto publicitário desenvolvido na campanha eleitoral de 2020 para prefeito da cidade de Recife-PE.

\section{Autoria e estilo: uma relação constitutiva}

Antes de adentrar o nosso entendimento acerca da autoria e do estilo, é necessária a compreensão de uma noção preliminar e mais geral que está na base de ambos: o sujeito. No âmbito da linguística e das teorias do discurso, ele, geralmente, é compreendido por dois vieses: 1 . uma entidade individual ativa e única, agente criador responsável pela produção de enunciados; 2 . entidade passiva, subjugada socioideologicamente, reprodutor de um sistema linguístico o qual usa instrumentalmente para se comunicar e que, ideologicamente, não cessa de agir sobre ele.

O primeiro tem uma representação significativa na estilística vossleriana e encontra uma grande resistência nos escritos de Volóchinov. Herdeira de uma perspectiva humbolditana do sujeito como energia, agente ativo da comunicação, essa perspectiva entende a comunicação verbal e a criação artística como produto de uma mente criativa. 
Os atos de linguagem são sempre atos de criação individual. Portanto, nesse terreno, a análise linguístico-estilística seria, antes de tudo, a busca pelas marcas individualizantes do sujeito. Tem-se aí uma perspectiva psicologizante da linguagem e do sujeito, em oposição ao sujeito como instância social.

O segundo, ao contrário, compreende o sujeito como uma entidade que reflete as ideologias e, portanto, submetida às condições sociais que sobre ela se abatem. Boa parte das teorias marxistas, especialmente a derivada dos estudos de Althusser, caminha nessa direção. Nesse sentido, a linguagem materializaria apenas o reflexo da ideologia que sujeitos, passiva e inconscientemente, reproduziriam. O único espaço de individualidade, isto é, de liberdade, que teriam seria exatamente a liberdade de assujeitar-se à ideologia que os atravessa.

Nesses termos, social e individual se opunham nas concepções das diferentes correntes linguístico-filosóficas, ora privilegiando o individual, ora o social. Nesse ínterim, os estudos dialógicos do Círculo de Bakhtin propunham uma visão mais radical do sujeito, entendendo-o em termos de sua integralidade, isto é, o sujeito é uma instância ao mesmo tempo individual e social. Conforme tal perspectiva, a interação passa a ser a base do desenvolvimento humano e, consequentemente, o fundamento primeiro da criação verbal.
Por essa ótica interpretativa, podemos dizer que um princípio fundante perpassa os estudos do Círculo: "O inter-humano é constitutivo do humano" (TODOROV, 2011, p. xxvi). Dessa percepção mais geral, Bakhtin (2013) compreende que a forma basilar do desenvolvimento da língua é o dialogismo, isto é, a constante interação entre os discursos e entre os sujeitos, sendo que essa interação os constitui mutuamente. Assim,

O sujeito é pensado em termos de uma interação constitutiva com a sociedade: assim como precisa da sociedade para existir como tal, o sujeito constitui, em sua relação com outros sujeitos, essa mesma sociedade [...] toda relação entre ao menos duas pessoas já é um evento social, uma relação social e histórica que envolve toda a sociedade, do ponto de vista de seus diferentes recortes possíveis num dado momento histórico (SOBRAL, 2009, p. 47).

Essa percepção anula a dualidade individual $\mathrm{x}$ social, retomando a integralidade do sujeito cognoscente: ele é determinado por condições sociais ao mesmo tempo em que também é agente modificador dessa realidade.

Nesse sentido, a relação do sujeito com a língua ganha uma nova acepção. Se do ponto de vista das respectivas correntes linguístico-filosóficas ora o centro organizador da língua era o indivíduo, ora o próprio sistema linguístico abstrato - entendido como socialmente determinante, isto é, um instrumento preexistente na sociedade pronto para ser usado pelos indivíduos - para o Círculo 
[...] nem sistema abstrato, nem produto da consciência individual, a língua só tem sentido na interação verbal, pois ela é fruto da relação entre os indivíduos. Ela é antes de tudo um fato social, não no sentido de um fenômeno inerte, pronto para ser usado pelos indivíduos, tampouco fruto apenas da consciência individual; ela é produto das relações sociais, das necessidades coletivas, dos sujeitos sócio e historicamente organizados em intensa interação. Um signo existe sempre como resposta a um outro signo, dirão os estudiosos russos, e é na (inter)relação entre os indivíduos que os sentidos emergem de cada signo linguístico (SILVA, 2016, p. 19-20).

Essa compreensão leva ao entendimento de que os sujeitos se constituem mutuamente na/pela linguagem via comunicação socioverbal. No momento em que enuncia, o sujeito interage levando em consideração o outro, a quem ele se dirige. Esse fato molda a forma de enunciar e cria imagens objetificadas dos interlocutores. Assim, o leitor/ouvinte percebe por meio do enunciado uma imagem representada daquele que enunciou assim como aquele que enuncia projeta em seu dizer a imagem dos destinatários. Estas forças intersubjetivas, portanto, determinam sempre o acabamento de todo enunciado. Em outras palavras,

A produção [de enunciados] ocorre no âmbito de interações dialógicas entre sujeitos inseridos em contextos sociais e históricos; os discursos produzidos circulam nesses contextos sociais e históricos, de acordo com as coerções, e a recepção depende desses contextos sociais e históricos para realizar-se (SOBRAL, 2009, p. 49).

Assim compreendida a noção de sujeito que aqui adotamos, passemos ao enten- dimento das categorias centrais desse trabalho: autoria e estilo. Já observamos que a interação verbal é o fundamento basilar da comunicação humana e que, por essa razão, os sujeitos se manifestam nas diferentes representações que os interlocutores têm uns dos outros projetadas nos signos que materializam diferentes discursos em enunciados concretos.

Partindo dessa percepção, Bakhtin (2011) afirma que autorar é assumir constantemente uma posição avaliativa em relação ao outro. $\mathrm{O}$ estudioso russo se refere, nesse caso, à relação entre autor e personagem na atividade estética, porém o faz demonstrando que tal fato se dá em todas as esferas de atividade humana, 0 que difere é a forma como essa tomada de posição acontece em relação à natureza de cada esfera. Na literatura, o autor reage à personagem como um todo; na vida, o sujeito reage às atitudes pontuais de outros sujeitos em situações históricas específicas.

Concernente a esse pressuposto, há aqui uma distinção importante a se fazer: é necessário não confundir o autor com a pessoa humana psicologicamente individualizada. $\mathrm{O}$ autor é uma entidade imanente à obra, uma posição recortada pelo sujeito para refratar determinada posição axiológica em seu enunciado. Assim, Bakhtin (2011) difere a pessoa real do autor-criador: este é a refração daquele no enunciado. $\mathrm{E}$ é nesse ponto que a abordagem bakhtiniana de autor nos é especialmente relevante, pois Ba- 
khtin caracteriza o autor como uma posição axiológica, o que está de acordo com o conjunto da filosofia do Círculo de que

[...] a grande força que move o universo das práticas culturais são precisamente as posições socioavaliativas postas numa dinâmica de múltiplas inter-relações responsivas (FARACO, 2009, p. 90).

Nesses termos, podemos concluir que todo ato humano é sempre uma resposta em relação a outros atos de outros homens, ou seja, é sempre uma tomada de posição axiológica frente ao mundo. Como consequência desse raciocínio, se entendermos o enunciado como um ato, devemos considerar que todo texto, enquanto materialidade enunciativa, parte de uma posição axiológica, isto é, toda estruturação verbal ou verbo-visual que constitui um enunciado concreto é determinada previamente pela posição valorativa que o sujeito no mundo recorta para refratar valores no processo enunciativo. Logo, todo texto, independentemente de ter uma assinatura ou um responsável, tem um autor-criador: uma posição axiológica que produz refrações frente ao mundo em um dado enunciado historicamente realizado.

A pessoa no mundo (o escritor, o artista, o fotógrafo, o padre, o pastor, o jornalista, o publicitário etc.) trabalha sempre com uma voz segunda: "um ato de apropriação refratada de uma voz social qualquer de modo a poder ordenar um todo estético" (FARACO, 2009, p. 92), ou, mais amplamente, ordenar um todo enunciativo. Assim, a concepção de autor em Bakhtin

[...] se reveste de materialidade verbal e o autor-criador passa a ser identificado à voz social que cria e sustenta a unidade do todo artístico (FARACO, 2009, p. 94).

Volóchinov (1976) também compreende $o$ autor como uma posição axiológica, mas dá atenção especial a um terceiro elemento que entra no jogo de relações entre o autor e o tema do enunciado: 0 leitor ou receptor. Se para Bakhtin o autor é uma instância imanente ao enunciado, para Volóchinov é necessário não confundir o receptor com o público real,

[...] ambos são compreendidos como unidades imanentes à obra. Eles (autor e leitor) determinam a obra como um todo reciprocamente, ocupando, no interior dela, cada um uma posição axiológica (SILVA, 2016, p. 34).

Tudo que expusemos até aqui implica uma percepção de que as escolhas dos signos que usamos para enunciar são determinadas pelos interesses comunicativos que temos em mente em relação aos nossos interlocutores. Por interlocutores temos em mente o público ao qual o enunciado é endereçado; isso implica dizer que, mesmo na ausência física dos indivíduos, é possível projetar uma representação valorativa destes nos enunciados. Isso porque, ao enunciarmos, estamos jogando com valores ideologicamente determinados, isto é, projetamos no enunciado os valores dos interlocutores e não os dos 
seres biológicos em si. E essa projeção sempre constante determina de antemão a seleção, organização e distribuição dos signos verbais e não verbais no interior do enunciado.

Portanto, as marcas desse processo enunciativo ficam depositadas nos enunciados, materializadas nas escolhas lexicais, fraseológicas, na organização dos parágrafos, nas escolhas dos discursos citados de outrem, nas construções morfológicas, nos neologismos, na organização das imagens e outros recursos semióticos.

Aqui, já estamos no âmbito do estilo, visto que, para Bakhtin (2011), toda escolha linguística (por extensão também as não verbais) que utilizamos para interagir é uma ação estilística. Ora, se o enunciado é determinado pelas forças intersubjetivas que o atravessam, o estilo é o produto da interação entre $o$ sujeito e o mundo, determinado pelas posições axiológicas postas em jogo pela enunciação, uma vez que

[...] a enunciação está na fronteira entre a vida e o aspecto verbal [e não-verbal] do enunciado; ela, por assim dizer, bombeia energia de uma situação da vida para o discurso verbal, ela dá a qualquer coisa linguisticamente estável o seu momento histórico vivo, o seu caráter único (VOLÓCHINOV, 1976, p. 9).

Nesse contexto, o estilo deixa de ser compreendido como uma particularidade de um indivíduo e passa a produto da relação entre os valores humanos. Nas palavras de Volóchinov, (1976, p. 15)
[...] “o estilo é o homem”, dizem; mas poderíamos dizer: o estilo é pelo menos duas pessoas ou, mais precisamente, uma pessoa mais seu grupo social na forma do seu representante autorizado, o ouvinte - o participante constante na fala interior e exterior de uma pessoa.

Assim, autor e ouvinte participam da enunciação como representações valorativas dos sujeitos no mundo. $\mathrm{E}$ essas posições podem ser percebidas na materialidade do enunciado concreto a partir da análise da organização estilística realizada pelo autor no processo enunciativo. Onde há estilo, há autor, pois ambos se implicam na tessitura do enunciado.

A seguir, faremos a análise de um panfleto divulgado nas eleições de 2020 para prefeitura do Recife-PE, com a finalidade de demonstrar como autor e receptor encontram-se implicados na construção estilística do enunciado e que a relação entre eles, determinada pelas condições sócio-históricas de produção, é materializada na forma de posições axiológicas refletidas e refratadas no panfleto-enunciado.

\section{Autor e estilo no enunciado concreto panfleto}

Delineadas as categorias teóricas que sustentam nossa análise, é necessário situar a condição de produção sócio-histórica sob a qual o enunciado a ser analisado foi realizado a fim de compreendermos o que motivou a sua organização estilística e a materialização das posições axiológicas em jogo. 
Em meio à intensa polarização política do país desde a eleição presidencial de 2018, a eleição à prefeitura do Recife-PE contou com onze candidatos, no entanto, apenas quatro conquistaram eleitores suficientes para compor o quadro que realmente faria parte da disputa. Ao longo do processo, a disputa foi se afunilando e os candidatos do PSB e do PT despontaram como favoritos, sendo que o PSB apresentava vantagem. Nesse período, as campanhas eram pautadas em apresentações de projetos e construção da imagem positiva dos candidatos. Como consequência desse primeiro momento, assim foi projetada a última pesquisa Datafolha com as intenções de votos para o $1^{\circ}$ turno:
Figura 1 - Pesquisa de intenção de voto para prefeitura do Recife-PE, $1^{\circ}$ turno.

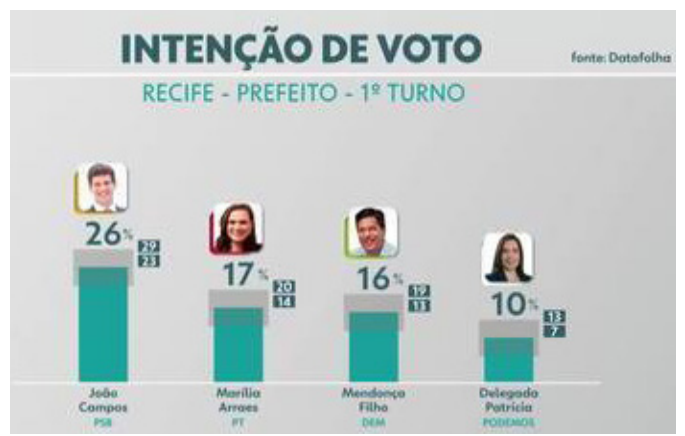

Fonte: DataFolha

Após o primeiro turno, as pesquisas se confirmaram, porém, a candidata do PT, Marília Arraes, obteve mais votos do que o esperado, correspondendo a um empate técnico com o candidato do PSB:

Figura 2 - Resultado do 1ํturno da disputa à prefeitura do Recife.

3 f politica.estadao.com.br/eleicoes/2020/cobertura-votacao-apuracao/primeiro-turno/pe/recife

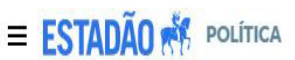

Eleições 2020

\section{PREFEITO}

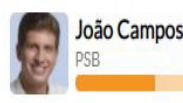

$29,17 \%$

DISPUTA $2^{\circ}$ TURNO

$04^{\circ}$ Delegada Patricia

PODE

$05^{\circ}$ Carlos

PSL

$06^{\circ}$ Coronel Feitosa

PSC

ATUAUZADO EM: 15/11/2020-22:23:05|FONTE: TSE

Fonte: Estadão/TSE.

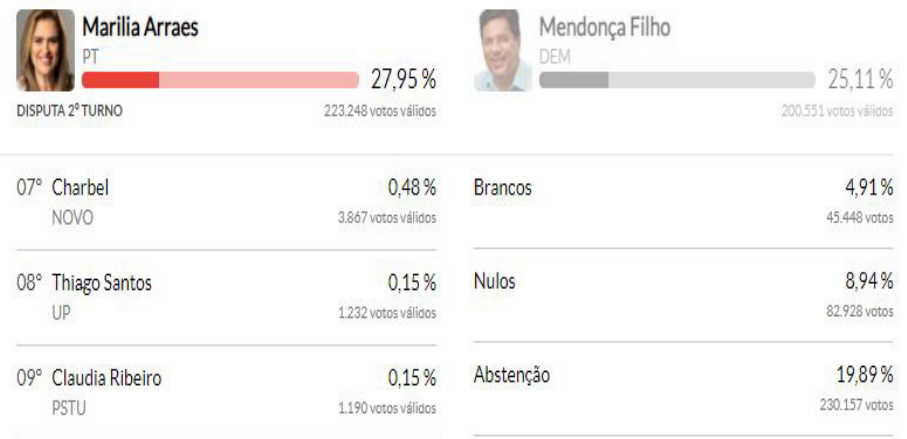


Esse cenário já apresentava indícios de que a candidata petista poderia ser alavancada no $2^{-}$segundo turno, acirrando ainda mais a disputa, o que exigiria uma mudança de estratégia no marketing político. Após a pesquisa de intenção de votos para o $2^{\circ}$ turno ser divulgada, Marília Arraes surge liderando a disputa:

Figura 3 - Pesquisa de intenção de voto para a prefeitura do Recife, $2^{\circ}$ turno

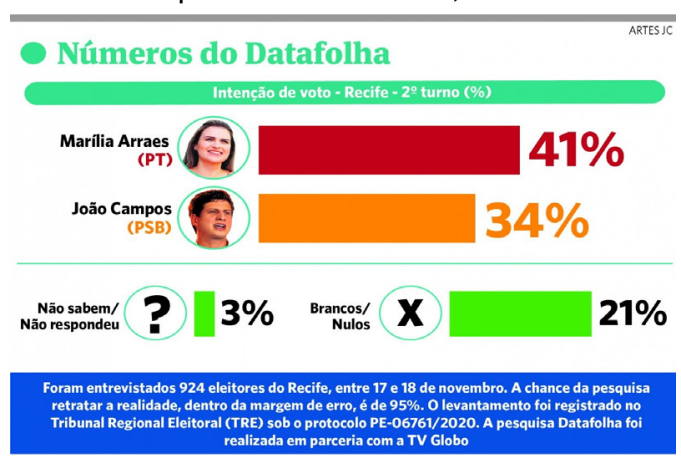

Fonte: DataFolha

Tal cenário muda completamente a orientação discursiva das propagandas eleitorais. De apresentação de propostas de governo, o PSB passou a atacar a imagem da candidata do PT, a fim de conquistar a opinião pública pela aversão à candidata.

Difundida através das redes sociais de forma viral e panfletária, as propagandas apelavam para um grupo aparentemente bem definido: os cristãos. Após mais de uma semana viralizando nas redes socais, as propagandas foram impugnadas pela justiça, com base no fato de suas informações configurarem fake News. O partido, então, converteu o panfleto digital numa versão impressa e passou a distribuí-lo em massa nas ruas da grande Recife-PE. É esse material que constitui o enunciado da análise desse artigo. Segue o mesmo:

Figura 4 - Panfleto do PSB em campanha para $2^{\circ}$ turno à prefeitura de Recife-PE

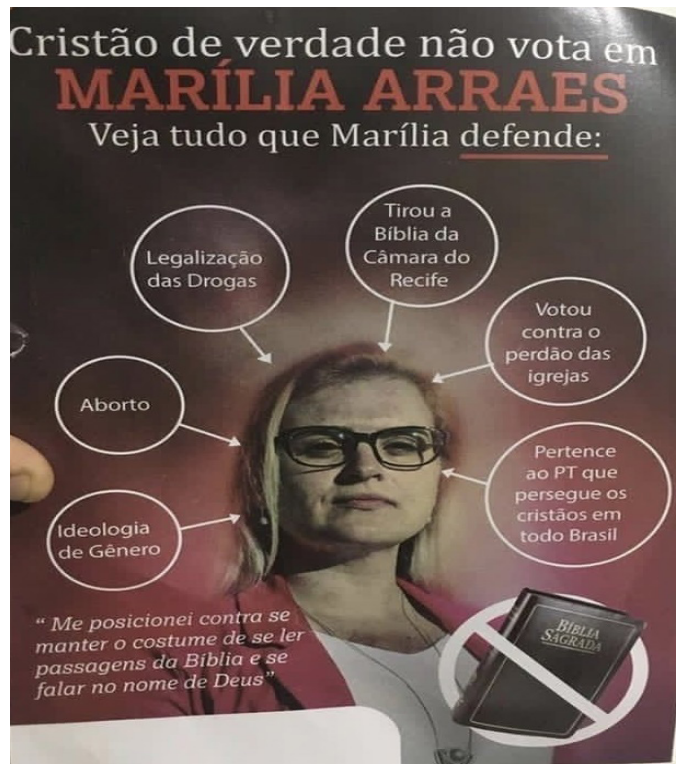

Fonte: https://twitter.com/tiagobarbosa_/status/ 1330915640249561088. Imagem editada.

O panfleto propagandístico-eleitoral é constituído por elementos verbo-visuais e tem como finalidade conquistar a opinião pública de um grupo específico de eleitores: os cristãos. Porém, é necessário considerar, ao analisá-lo, aspectos dialógicos que nos permitem fazer um recorte ainda mais específico dentro do grupo dos cristãos: os evangélicos. Ao longo dessa análise este dado ficará mais evidente. 
Considerada, hoje, a maior bancada do congresso, os evangélicos são o grupo religioso que mais cresce no Brasil. Nas eleições de 2018 ele teve papel significativo no resultado da disputa presidencial. Entretanto, este é um público de vertente ideológica conservadora, diferente do que propunha o PSB. No entanto, a situação de produção de tal enunciado requeria uma estratégia de marketing que conquistasse a opinião desse eleitorado. Para isso, o panfleto foi estilisticamente estruturado de forma que os sentidos que dele emanassem evocassem elementos fundamentais da tradição religiosa.

Para entendermos o funcionamento do projeto estilístico do enunciado, devemos considerar antes a posição axiológica responsável pelo acabamento do todo enunciativo. Em outras palavras: quem é o autor-criador do panfleto-enunciado? Não podemos confundi-lo com o PSB, pois não há vestígios do partido político no texto: nem sigla, nem nome do candidato. Muito diferente disso, o partido parece nem participar da ação enunciativa. Antes, o que se encontra é uma convocação que apela aos "cristãos" para que não votem na candidata do PT. O enunciado como um todo soa como uma voz sem nome, mas axiologicamente carregada de ideologia cristã conservadora que se opõe aos valores progressistas da esquerda petista.

É a partir dessa posição axiológica que todo enunciado é organizado, tanto verbal quanto visualmente. Podemos analisar o movimento estilístico do enunciado a partir de dois aspectos: 0 jogo cromático e o discurso reportado. Comecemos pela seleção, organização e distribuição das cores no enunciado.

$\mathrm{O}$ vermelho predominante no panfleto aparece em oposição a outras cores semanticamente significativas no campo político, como o azul e amarelo do PSDB, por exemplo, sendo, portanto, ideologicamente, oposto à voz que emerge do interior do enunciado. No entanto, ele converge com o símbolo também vermelho do PSB, que não poderia, nesse caso, aparecer na cena com filiação ideológica próxima à da candidata ao pleito. Assim, esse aspecto cromático do enunciado põe em cena apenas uma representação política que se filia ao campo progressista petista, reforçado na roupa (blazer) da candidata, tomado como ideologia contrária às políticas de perfil conservador.

Aqui, o jogo com as cores demarca as tensões entre o centro axiológico que enuncia e o partido do PT. Em destaque sobre o fundo vermelho encontra-se um conjunto de enunciados verbais em branco, que remete à ideia de clareza, limpeza, paz e santidade ao mesmo tempo em que soa como a voz socioideológica que contrasta com o escarlate da candidata.

Ressalte-se, ainda, que no panfleto-enunciado as palavras em branco soam como uma voz social que denuncia atos e crenças da petista. $\mathrm{O}$ único trecho em 
branco em que aparece a primeira pessoa referindo-se a Marília Arraes está entre aspas, demarcando-o como uma fala da candidata, isto é, fala-se dela usando as palavras dela, mas com distanciamento. Ou seja, o branco em destaque não se mistura semanticamente com o vermelho, mas faz oposição a ele e denuncia-o.

Assim, a própria seleção e organização de distribuição das cores são orientadas a partir da vinculação valorativa que têm os entes sociais e ideológicos do discurso refratada no enunciado. Por esse motivo, o vermelho está no nome da candidata, no fundo que a cerca e no blazer que a encobre. Marília Arraes se torna a própria encarnação do PT. Mas é exatamente o PT o inimigo a ser combatido. Obviamente, não por todos os eleitores, mas pelos eleitores cristãos evangélicos. Vejamos como esse dado está dialogicamente determinado no interior do enunciado, por meio da análise do discurso reportado.

Ao observarmos a distribuição verbal no interior do enunciado, evidencia-se um jogo de deslocamentos de sentido por meio de paráfrases e citação em estilo direto. Uma perspectiva dialógica de análise deve sempre levar em consideração que o discurso nasce como uma réplica viva em relação a outros discursos (BAKHTIN, 2011), mas também que todo enunciado nasce a partir de outro, embora nem sempre essa relação constitutiva com o enunciado outro seja perceptível na materialidade enunciativa. No entanto, as formas de organização discursiva que mais evidenciam essa relação são as diferentes formas de inserção do discurso alheio no interior do enunciado. As paráfrases são um desses recursos. Como afirma Volóchinov (2017, p. 249), o

[...] "discurso alheio" é o discurso dentro do discurso, o enunciado dentro do enunciado, mas ao mesmo tempo é o discurso sobre o discurso, o enunciado sobre o enunciado.

À primeira vista o enunciado que inicia o panfleto é uma convocatória aos cristãos: "Cristão de verdade não vota em Marilia Arraes”. Aqui, apesar do apelo aos cristãos, retoma-se um enunciado de outra conjuntura histórica recente, remetendo ao discurso evangélico contra os partidos de esquerda, especialmente o PT, nas eleições de 2018. À época, o pastor Feliciano ${ }^{1}$ encabeçou uma campanha com os dizeres "Cristão de verdade não vota no PT-PCdoB-PSOL". Esse discurso ganhou eco em diferentes mídias e na imprensa:

Figura 5 - Notícia no DM sobre "Quem é cristão não pode votar no PT"

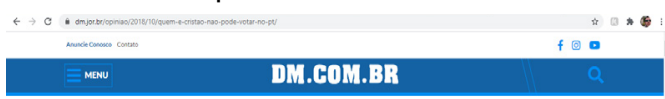

cosinto

Quem é cristão não pode votar no PT

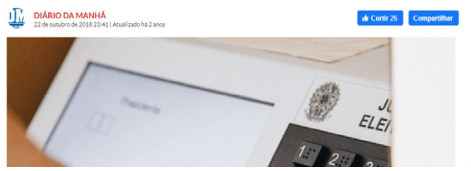

(6)

Fonte: https://www.dm.jor.br/opiniao/2018/10/quem-e-cristao-nao-pode-votar-no-pt/ 
Figura 6 - Postagem do Pr. Renato Vargens sobre "13 razões para não votar no PT"

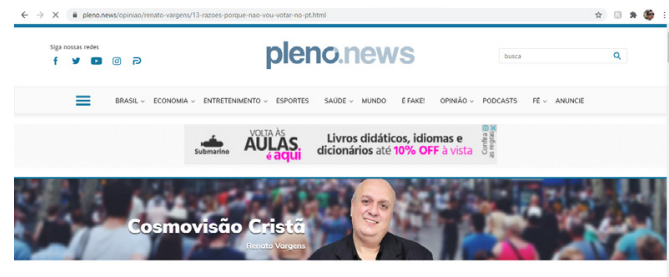

13 razões porque não vou votar no PT

Fonte: https://pleno.news/opiniao/renato-vargens/13-razoes-porque-nao-vou-votar-no-pt.html

No enunciado em análise, esses dizeres são parafraseados, substituindo o PT por Marília Arraes. Esta, agora, inserida como objeto central do discurso, passa a ganhar contornos valorativos e torna-se imagem representativa do PT em pequena escala. Mas também uma espécie de personagem inserida na propaganda panfletária como objeto do discurso. Assim, "o clima social da palavra que cerca o objeto obriga as facetas de sua imagem a entrarem no jogo" (BAKHTIN, 2015, p. 50) e nas regras de disposição do discurso orientadas pelo autor.

Como a natureza do discurso é dialógica, a seleção das palavras, das frases ou de enunciados inteiros nunca surge apenas do repertório linguístico depositado no sistema da língua, mas das vivências históricas de discursos já realizados em diferentes momentos, por diferentes grupos ideológicos. Assim, ao retomar o discurso da campanha do pastor em outro momento político, as tensões ideológicas também são retoma- das para o interior da disputa política presente. É o enunciado do outro no interior do novo enunciado, mas também, inserido nesse novo momento, uma reafirmação do já-dito retomado. A seleção dessa paráfrase busca acionar na nova cena política o engajamento do público evangélico de um passado recente.

Para justificar o engajamento dos evangélicos, o autor insere novos elementos valorativos que caracterizam a imagem da candidata como oposição aos valores cristãos por meio de um aposto construído pela imagem da candidata e alguns balões com afirmações em seu interior: "Veja tudo que Marília defende: ideologia de gênero, aborto, legalização das drogas, tirou a Bíblia da Câmara do Recife, votou contra o perdão das igrejas, pertence ao PT que persegue os cristãos em todo o Brasil". Isso, entretanto, não é feito de uma forma aleatória. A disposição dos balões, assim como a centralidade da candidata na imagem, é estilisticamente organizada para evocar um outro momento histórico: esse formato de exposição da figura petista é uma paráfrase (verbo-visual) que retoma o histórico evento do PowerPoint produzido pelo Procurador da República Deltan Dallagnol $^{2}$ com a finalidade de acusar o ex-presidente Lula por organização criminosa e corrupção: 
Figura 7 - PowerPoint de Deltan Dallagnol para acusação do ex-presidente Lula

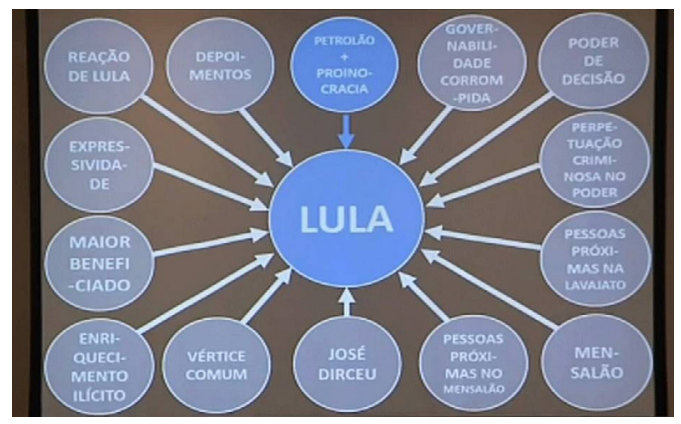

Fonte: O GLOBO

Parafrasticamente, o ex-presidente é substituído pela candidata à prefeitura do Recife e nos balões são substituídas as acusações de corrupção por atos de cunho moral progressistas associados a perseguição aos cristãos e a seus símbolos. Identificada ao PT, a candidata é colocada na posição daquela que está sendo julgada por seus atos contra os princípios cristãos evangélicos. Novamente, o que está em jogo não é um indivíduo ou um grupo de indivíduos, mas duas posições axiológicas contraditórias atravessadas por ideologias que se repelem, motivadoras da seleção, organização e distribuição discursiva de elementos linguísticos e visuais realizadas por uma posição axiológica que sentimos ao longo do enunciado se comunicando com o "eleitor cristão".

Como nos ensina Bakhtin (2015, p. 21), independentemente de sua finalidade, o discurso "não pode deixar de orientar-se 'dentro do que já foi dito', 'do conhecido', da 'opinião geral'”. É apelando para esse conhecido, essa opinião geral sobre um acontecimento discursivo relevante historicamente que o autor-criador dispõe cada elemento verbo-visual. Por isso, nessa nova conjuntura, tais elementos são inseridos sintaticamente num aposto, o que semanticamente remete a uma explicação sobre algo dito anteriormente. No caso em tela, esse aposto justifica o enunciado que inicia o panfleto: "Cristão de verdade não vota em Marília Arraes”. Em outras palavras, a opção sintática por um aposto não serve apenas para criar uma imagem de oposição da candidata aos valores cristãos, mas também para justificar a convocação dos cristãos ao ato político.

Por fim, a técnica da citação em estilo direto com aspas de distanciamento para delimitar as fronteiras do enunciado proferido por Marília Arraes das palavras do autor: "Me posicionei contra a leitura da bíblia no plenário". No caso em pauta, ao trazer este trecho do discurso do outro com as próprias palavras do outro para o interior do panfleto, o autor-criador busca confirmar o motivo pelo qual seus interlocutores devem se posicionar contra a candidata do PT: as palavras da candidata surgem como prova contra si e reafirma a convocação enunciada.

Em outras palavras, ao citar as palavras da própria candidata a respeito da leitura da Bíblia, busca-se sustentar toda a retórica do conjunto enunciativo do panfleto, na tentativa de gerar uma 
tensão entre a imagem dos interlocutores em foco e os supostos valores da candidata. As palavras dela funcionam como uma "prova do crime" pelo qual ela está sendo "julgada". Paralela à citação se encontra a imagem de uma Bíblia com um símbolo de interdição, reforçando a ideia de que Marília Arraes interditou "a Palavra de Deus" na Câmara Municipal de Recife, sentido que podemos evocar pelo contexto intraverbal do enunciado, no último balão, à direita, com seta que aponta para a candidata: "Pertence ao PT que persegue os cristãos em todo Brasil”.

Como pode se entrever das análises, no discurso propagandístico das campanhas eleitorais, a emergência de um enunciado é determinada pelo movimento do eleitorado, mas também orienta este mesmo movimento em função da conquista da opinião púbica, uma vez que a opinião pública "[...] também se delineia através do olhar que a contempla" (CHARAUDEAU, 2016, p. 43), identificando-se ou não com ele. Nesse contexto, o movimento autoral manifesta-se em sua orientação estilística em direção ao objeto e ao interlocutor:

Assim, a produção é influenciada em sua nascente pelas condições de circulação e de recepção, e também influencia essas condições (SOBRAL, 2009, p. 49).

Na direção do objeto, o autor mergulha na seara dos já-ditos, discursos outros (e de outros) sobre seu objeto de dizer e seleciona aqueles que lhes são proveitosos, tendo em vista suas finalidades sobre o interlocutor. Os discursos selecionados são (re)organizados e distribuídos ao longo de seu enunciado sempre permeados por valores pertinentes à interlocução suscitada.

$\mathrm{Na}$ direção do interlocutor, o autor suscita sempre uma resposta. Esta pode até ser antecipada no próprio corpo do enunciado, como na retórica, mas também pode ser solicitada como uma ação social a ser executada pelos interlocutores, como nas propagandas políticas.

Todo jogo valorativo que expusemos no enunciado em análise materializa-se nas escolhas estilísticas empregadas em função, como demonstramos, do interlocutor cristão-evangélico-eleitor. Aqui ressaltamos que, em todo momento que se evoca uma voz religiosa, ela advém de um pastor evangélico ou de um espaço discursivo midiático evangélico. Portanto, ao evocá-la, faz-se uma convocação direcionada a tal público. Isso não impede, entretanto, que o enunciado não atinja os demais cristãos, uma vez que é a palavra "cristão" que aparece recorrentemente ao logo de todo texto. No entanto, as seleções estilísticas realizadas apontam para sentidos e ações que tocam mais de perto o público evangélico. Não à toa, a campanha do PSB foi apoiada pelo maior representante do (neo)pentecostalismo no Brasil, o pastor Silas Malafaia ${ }^{3}$, reiterando o dialogismo presente no enunciado-panfleto: 
Figura 8 - Manchete sobre pedido de votos para João Campos por Malafaia

ELE!̨̧OES 2020

RECIFE

\section{Malafaia pede voto para João Campos no \\ Recife: "Não podemos votar em PT"}

Fonte: https://noticias.uol.com.br/eleicoes/2020/11/28/
Os resultados das pesquisas de boca de urna para o segundo turno demonstram como a recepção desse discurso orientou a opinião pública dos grupos religiosos.

Figura 9 - Resultado da boca de urna do segundo turno para eleições do Recife-PE

Depois de amanhä/amanhã haverả o segundo turno das eleiçōes para prefeito da cidade de Recife. Se o segundo turno da eleiçăo fosse hoje, em quem você votaria:

(Resposta estimulada e ủnica, em \%)

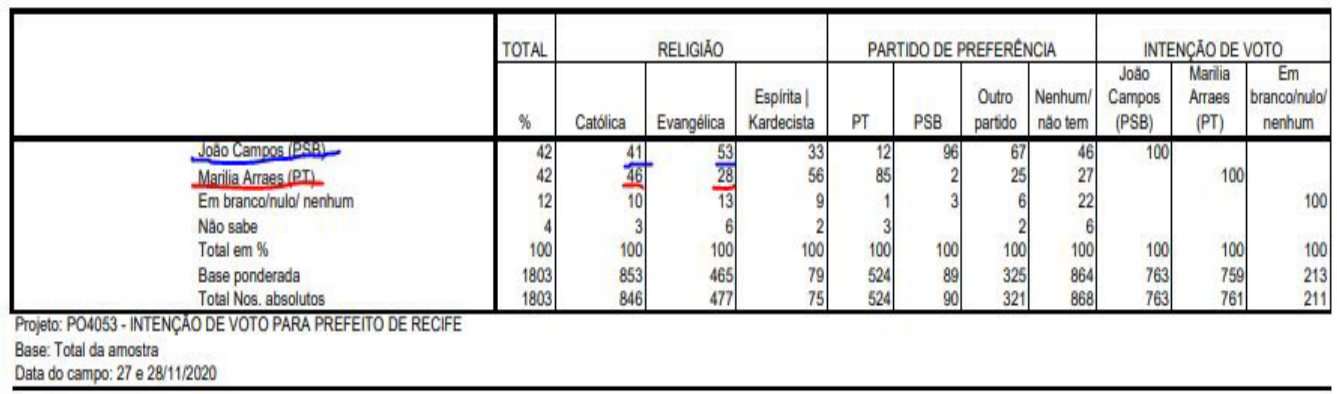

Fonte: DataFolha.

Note-se que entre os católicos há quase um empate técnico, com leve vantagem para Marília Arraes. Entre os evangélicos, João Campos aparece com quase o dobro de vantagem em relação à adversária. É a esse público que a posição axiológica autoral diz: "não vote Marília Arraes", "Não vote no PT". E é essa outra posição axiológica impelida pelo e resignada aos preceitos cristãos que o enunciado-panfleto convoca a uma atitude responsiva ativa: não votar na candidata do PT.

O enunciado panfleto não evoca sentidos para convocar eleitores, mas convoca iguais posições axiológicas que com ele comungam valores e crenças. Em última instância, a posição autoral se converte em um cristão evangélico que convoca outros evangélicos (mas também outros cristãos) a um ato religiosamente significativo, não necessariamente um ato puramente político. Em outras palavras: $o$ ato político converte-se em ato religiosamente significativo, em um jogo ideologicamente tenso, estilisticamente construído no interior do enunciado, porém determinado por questões sócio-históricas. Assim, autor, objeto e interlocutor são imanentemente construídos no interior do enunciado a partir de relações sociais concretas que vão além 
dele, mas que se encontram nele refletidas e refratadas.

\section{Considerações possíveis}

Discutir conceitos como autor e estilo é um desafio para o analista de discurso, uma vez que tais categorias não encontram um lugar comum ou um consenso entre as diferentes abordagens linguísticas, literárias, estilísticas ou retóricas. É função do analista, portanto, situar o lugar de sua análise entre outras perspectivas teóricas.

Em nosso trabalho, todo percurso analítico é delimitado pelos estudos dialógicos do discurso. Logo, as interpretações analíticas que advêm de nosso material devem ser compreendidas como "uma" interpretação a partir do arcabouço teórico que nos serve de base. Isso significa que esta é uma entre as formas possíveis de leitura do objeto e seus dados.

No entanto, acreditamos ter alcançado o objetivo a que nos propusemos, que foi o de demonstrar que autor e receptor encontram-se imanentemente implicados na construção estilística do enunciado e que a relação entre eles, determinada pelas condições sócio-históricas de produção, é materializada na forma de posições axiológicas refletidas e refratas no interior do enunciado.

\section{Authorship and style: a concrete case of the author- creator in the pamphlet discursive gender}

\section{Abstract}

The objective of this work is to demonstrate that the author and the interlocutor are immanently involved in the stylistic construction of the statement and that the relationship between them, determined by the sociohistorical conditions of production, is materialized in the form of reflected and refractory axiological positions in the statement. For this purpose, a pamphlet released in the 2020 elections for the city of Recife-PE was analyzed. As a theoretical framework, we used the categories of author and style based on the theoretical apparatus of Bakhtin (2011), Volóchinov (2002), among others.

Keywords: Author; interlocutor; style.

\section{Notas}

1 Marco Antônio Feliciano é um pastor da Catedral do Avivamento, uma igreja neopentecostal ligada à Assembleia de Deus, e deputado federal brasileiro.

2 Deltan Dallagnol, Procurador da República, ficou conhecido nacionalmente por integrar e coordenar a força-tarefa da Operação Lava Jato, que investigava supostos crimes de corrupção na Petrobras e em outras estatais.

3 Silas Lima Malafaia é um pastor protestante neopentecostal brasileiro, líder da Assembleia de Deus Vitória em Cristo. É Presidente da Editora Central Gospel, além de ser vice-presidente do Conselho Interdenominacional de Ministros Evangélicos do Brasil (CIMEB), entidade que agrega cerca de oito mil pastores de quase todas as denominações evangélicas brasileiras. (Wikipedia). 


\section{Referências}

BAKTHIN, M. M. Estética da criação verbal. 6 ed. São Paulo: Editora WMF Martins Fontes, 2011.

BAKTHIN, M. M. Teoria do romance I: a estilística. Tradução de Paulo Bezerra. São Paulo: Editora 34, 2015.

BAKTHIN, M. M. Problemas da poética de Dostoievski. 5. ed. Rio de Janeiro: Forense Universitária, 2013.

FARACO, C. A.. Linguagem \& diálogo - as ideias linguísticas do Círculo de Bakhtin. São Paulo: Parábola Editorial, 2009.

SILVA, E. C. S.. Autoria na pregação religiosa neopentecostal. 2016. 120 f. Dissertação (Mestrado em Linguística) - Universidade Federal da Paraíba, João Pessoa, 2016.

FOUCAULT, M. O que é um autor? Portugal: Veja/Passagens, 2002.

SOBRAL, A. Do dialogismo ao gênero: as bases do pensamento do círculo de Bakhtin. Série Ideias sobre a Linguagem. São Paulo: Mercado das Letras, 2009.

CHARAUDEAU, P. A conquista da opinião pública: como o discurso manipula as escolhas políticas. Trad. de Angela M. S. Corrêa. São Paulo: Contexto, 2016.

SAUSSURE, F. de. Curso de linguística geral. Tradução de Antônio Chelini, José Paulo Paes e Isidoro Blikstein. 28. ed. São Paulo: Cultrix, 2012.

TODOROV, T. Prefácio à edição francesa. In: BAKTHIN, M. M. Estética da criação Verbal. 6 ed. São Paulo: Editora WMF Martins Fontes, 2011.

VOLOCHINOV, V. N. [1926]. Discurso na vida e na arte: sobre a poética sociológica. Trad. de Carlos Alberto Faraco e Cristóvão Tezza da edição inglesa de TITUNIK, I. R. "Discourse in life and discourse in art - concerning sociological poetics". In: VOLOSHI-
NOV, V. N. Freudism. New York: Academic Press, 1976.

VOLÓCHINOV, V. Marxismo e filosofia da linguagem. 10. ed. São Paulo: HUCITEC, 2002. 